\title{
Factors Influencing Teachers' Job Satisfaction: A Case Study Of Public Secondary Schools In Buraidh City Saudi Arabia
}

\author{
Hind Al Ajlan \\ Graduate Programs, College of Business and Economics \\ Qassim University, Saudi Arabia
}

\begin{abstract}
This study is conducted for the purpose of investigating the dynamics influencing teachers' job satisfaction in the public secondary schools in Buraidah. This research is quantitative; to study the factors that influence teachers' job satisfaction at secondary public schools in Buraidah city. Data has been collected by using a questionnaire, distributed to 150 teachers in Buraidah, Saudi Arabia. Analysis and discussion of data gathered from the questionnaire is done with descriptive statistics and the use of factor analysis, correlation, reliability and multiple regression analysis to test the significant dynamics influencing teachers' job satisfaction in public secondary schools in Buraidah city. The kay results proved that, remuneration, school manager and working conditions has influence on the teachers' job satisfaction. Remuneration has the great effect on the teachers' job satisfaction at secondary public schools of the study.
\end{abstract}

Keywords: Job satisfaction, working conditions, School manager, Remuneration, schools.

\section{INTRODUCTION}

Education gives the students' knowledge and various skills, develops constructive attitudes, community development economically, socially and culturally and to create an individual to be a useful member of society building (Ministry of education, 2016). In order to spread scientific knowledge among humans, there must be teachers who acknowledge of this great responsibility; Teaching is one of the most important human occupations. A teacher is the person who creates the generations who are educated and cultured. It is a fact that all other professions could not exist without the teacher. In addition to all of the above, a teacher is the one who creates more creative students in various areas of life through their innovations in performing of their career. So the teaching profession is the only facility capable for building successful societies, it is the profession that creates scientists and intellectuals in various communities. Job satisfaction is an important feature in daily life and must be stressed upon by all means if organizations and individuals can develop and grow to the anticipated ends. In order to achieve the objectives of education satisfied and motivated teachers are required (Christopher, 2014).

\section{Background of the teachers in Saudi Arabia}

Teacher's performance is a reflection of the height of Job satisfaction. Therefore, the teacher's performance in class differs from another teacher. This difference is due to several factors surrounding the Job satisfaction of teacher, which affect the performance to do his best or prevent him from performing his work better.

In Qassim region of Saudi Arabia, there are 15,612 teachers in public education schools in the morning. According to a statistic of the Ministry of Education, there are 4442 female and 3559 male teachers at primary level, 2380 female and 1943male teachers at the middle level, 1992 female and 1296 male teachers at secondary level (Ministry of educacation, 2017). The aim of this study is to develop the teachers' job performance by knowing the impact of some factors on Job satisfaction of Saudi teachers in Qassim, from the perspective of Saudi teachers in 
secondary public schools in AL-Qassim. The data is collected by using a questionnaire to a group of teachers, who work in secondary public schools in Qassim, Saudi Arabia at government schools. The objective is to see their vision about the factors that distress Job satisfaction of Saudi teacher in Qassim.

\section{The problem statement}

The teacher is a key helper/planner of knowledge and plays a very significant role in nation building. It is therefore extremely important to find out how comfortable the teacher is in his/her place of work, termed teacher happiness from meeting a need or reaching a goal. What's more, it is also important to identify factors responsible for teacher job happiness from meeting a need or reaching a goal or unhappy disappointment. This study focuses on the impact of certain aspects on the job satisfaction of teachers.

\section{The objective of the study}

This study strives to achieve the subsequent objectives:

To define factors that affect teacher's job satisfaction in public secondary schools in Buraidah city.

1- To define the level to which the manager influences the job satisfaction of teachers from the perspective of teachers, at public secondary schools in Buraidah city.

2- To determine whether the working conditions influence teachers' job satisfaction from their perspective, at public secondary schools in Buraidah city.

3- To establish the extent to which remuneration influences teachers job satisfaction from their perspective, at public secondary schools in Buraidah city.

\section{Research questions}

1- How the manager of schools influences the teachers' job satisfaction, from the perspective of teachers at public secondary schools in Buraidah city?

2- How do working conditions influence teachers' job satisfaction, from the perspective of teachers at public secondary schools in Buraidah city?

3- How does remuneration influence teachers' job satisfaction, from the perspective of teachers at public secondary schools in Buraidah city?

\section{The scope of the study}

This study investigates factors that effect on Saudi teacher's job satisfaction in government schools. The study population is all public education schools, male and female, in Buraidah city in Qassim region, Saudi Arabia. The secondary level of general education in the morning. The sample study consists of stratified random sampling of 150 Saudi teachers (75 males and 75 female) from 30 schools (15 males and 15 female) schools in Buraidah city of al-Qassim in Saudi Arabia. Distributed as follows: 75males teachers from 15 secondary schools and 75 female teachers from 15 secondary school, in Buraidah city of Al-Qassim in Saudi Arabia.

Data has been composed through a survey circulated to all members of the sample. The dissemination of the results of this study outside its statistical community is determined by the similar extent of the external community of the current study community, the Qassim region teachers for the academic year 2017-2018. Teacher responses are determined in Buraidah city in Qassim region, Saudi Arabia covered by the measurement tool used in this study.

\section{The relevance of the study}

The importance of this study stems from the active role of teachers in government schools in the building of the student's scientific, social and psychological personality, job satisfaction that affects the teacher's level of performance in this building. It is therefore axiomatic that the 
development of the teacher's level of performance is closely linked to the identification of factors influencing teacher's job satisfaction in order to overcome all that could adversely affect its performance (Al-Omari, 2006). The importance of this study also comes through an attempt to identify the factors influencing job satisfaction of Saudi teachers in government schools. Because these factors have a major role to play in their level of commitment and their work, the current study is offered to those interested and based on the process of developing the teacher's performance. Clear insights help them to build realistic decisions about factors that may affect the job satisfaction of teachers, and then reflect on their performance within the classroom. The importance of this study is demonstrated by the disclosure of the impediments that faced teachers in general education, which can have a negative impact on their job satisfaction. These obstacles reflect realistic perceptions by teachers stemming from experience. Finally, the study may contribute to the provision of new research insights for those interested in job satisfaction of public school teachers for the and mechanisms for the development of their work.

\section{LITERATURE REVIEW}

The relationship between the job performance and job satisfaction is captivating the attention of the researchers for some years, where most of the inducing studies have been proved the progressive and good association among the performance of teacher's job and the job satisfaction. Though, the difference among those studies is related to dynamics which has the effect on teacher's job satisfaction. A research takes this matter into an account of factors which may affect the teacher's job satisfaction, completed by Koustelio et al. (2004) checked the role conflict, role ambiguity and the job satisfaction among the Greek teachers of physical education, and a degree to the role conflict and role ambiguity affect the job satisfaction. After administering the questionnaire showed to each member of the sample of mostly 61 teachers of physical education, the data obtained. Those teachers were selected in the programs of Greek "Sport for all". The analysis of data has been done by using a standard Multiple Regression Analysis which highlighted that role conflict and role ambiguity are important predictors of job satisfaction.

Moreover, Al-Rubaish et al. (2009) was investigated the condition of job satisfaction among an academic staff in the King Faisal University-Dammam (KFU-D) and checked the areas and groups that are at severe risk of being annoyed. Interpersonal relationships, responsibility, recognition, salary, work itself, gender, advancement, and working conditions made the independent variables. Despite this, job satisfaction was the only dependent variable. The data that was collected, analyzed by 15.16 version of SPSS. The calculations of the valid data have been carried out. Furthermore, the relationships of ISS and MDS that are continuous dependent variables over the subject groups that are employed, independent, standard deviations and means. Those were tested for the implication by degrees of F-values and freedom. JSR that is a variable of percentile dependent was contracted through the independent variables in Pearson's Chi-Square and two-by-two cross-tabulation was used for experimenting the significance and used for the size effect by Odd's ratio and 95 percent of its confidence interval. Moreover, the applied stepwise linear regression on multivariate evaluations, that was estimated by R2 and experimented by F-value. Statistically, the obtained results were measured if the value of $p<$ the mean of JSR (Job Satisfaction Rate) that remained 73.6 percent. The best and highest rates of job satisfaction were found in the three areas interpersonal relationships, supervision, and responsibility and rearmost in four others salary, working conditions, advancement and my work itself. The job satisfaction ratio was lesser in the females, Saudi nationals, below the age of 40 , people from the clinical medicine and the Department of Dentistry. 
In Pakistan, Ahmed et al. (2012) try to search the professional attitude of the teachers that they find by the factors like subject mastery, the methodology of the teachers' private characteristics and teaching. This study showed that the improvement in the factors proved helpful in enhancing the teacher's work. This research work is descriptive. Students, teachers and the principals of postgraduate colleges and the teachers of Khyber Pakhtunkhwa composed the samples for population research.

Three questionnaires are prepared for principals separately, to collect the data. Statistical techniques like mean, standard deviation, variance ANOVA and the average rating are used analyzing and interpreting the data. An aspect of the subject mastery is the highest level between the four factors of the professional performance of teachers. It has been proved by this study. With the help of attending the refresher courses service and the self-study can improve the teacher's knowledge. Teachers must increase their attention to their students if they want to improve their professional skills and want to improve their professional performance. Moreover, this study shows that the teachers can improve their personal qualities with the help of using normal language, separating the blocks of communication, practicing the key vocabulary, speaking clearly, and varying inflection, pitch and tone of voice in their classroom. The research proves that if teachers can make their performance on factors that are the attitude with students, subject mastery, teaching methodology, and the personal characteristics, then the best developers can be completed in professional performance and teaching expertise of teachers.

In the relatable study, Treputtharat and Tayiam (2013) checked that how the environment of school affected the job satisfaction of teachers in the primary education and what factors of school environment affected the job satisfaction of teachers. In this study, the population involved 2,316 school teachers, under an agency of Khon Kaen Primary informative service area 5 has been used. For determining the size of the sample that have 329 teachers, Krejcie and Morgan have been used. Similarly, the sampling method, Simple Random Sampling, used to get samples in a collection of the data.

The questionnaire like five-level rating scale grounded on the Likert scale was a research tool that is used in this research in which the data checked with the help of descriptive statistics involving Percentages, Frequency, Mean, Standard deviation (S.D.). The Inferential statistics that have "Pearson Product Moment Coefficient Correlation", building the equation of Regression for predicting the dependent variables with the help of Stepwise Multiple Regression Analysis. An independent variable is involved in a variable that was the environment of the school. Job satisfaction is the dependent variable by the composition of the Organizational environment. Independent variables contain responsibility, provided support, organizational structure, warmness, rewards, work practice standards, leadership, unity, cooperation, success, and communication. The dependent variables absorbed the job satisfaction that consisting of the Hygienic Factors, Motivational Factors, Work Characteristics, Recognition, Work Progress, Work Success, Relationship in the Work Office, Responsibility, Work Practice Situation, Government and Control, Occupational status, Security of Work Practice, Personal leaving, Policy and management, and Salary.

The discussed material is the findings from research, overall, the effect of the school's climate on the job satisfaction of teachers is very high. The unity and achievement are found with the maximum meanwhile lowermost was responsibility. Generally, the level of teacher's job satisfaction is very high. Similarly, the career features are found with the greatest meanwhile lowermost is income and the other concerned stipends. Almost six features of the 
organizational environment are affecting the job satisfaction of teachers involving reward, responsibility, unity, leadership, performance standard and success.

The research by Obineli (2013) accomplished to examine a teacher's insight related to the reasons for distressing job satisfaction. To lead this research study, four hypothesis uses in Ekwusigo Local Government Area of Anambra. The sample of research study involved 361 teachers. The sample's size contains 140 teachers. The collection of data has been done through self-designed questionnaires. Salary, promotion, gender, less experienced and experienced, work environment, service training, married and unmarried private and public sectors are independent variables. These independent variables as the factors affecting the dependent variables in the job satisfaction. For testing that hypothesis, the z-test was used. The results of the research study showed that there is a notable difference between male and female teachers in their perception of the salary as this problem is affecting job satisfaction. The results of the research study also showed that there is no as such difference between experienced and less experienced teachers in their insight of the promotion an outlook affecting the job satisfaction. The results clearly showed that there is no main difference between the teachers in public schools and in private schools in their point of view the service preparation is the factor affecting job satisfaction. Though the results showed the notable difference between married and unmarried teachers in their point of view the work atmosphere is a factor that affects the job satisfaction. To find the chunk of teaching recognized stress, self-esteem, self-efficacy, and demographic characteristics like age, gender, education, and teaching experience in predicting the job satisfaction.

In Ireland, Reilly et al. research with the sample size of 121 teachers of Irish primary school. In Ireland, the researched data has been collected from the teachers of eight primary schools. The hypotheses were tested with the help of multiple regressions, correlations, and means. The results showed that the analysis of variables accounted for variance of $22 \%$ in satisfaction of jobs of the teachers. Though, to the uniquely predictive difference, only the assumed stress was found with an increased level of the stress occupations which relates to the low levels of satisfaction of job. Rielly (2014) also found that how the factors in the professional lives of the teachers affected their satisfaction in the workplace and how the satisfaction of job affects impermeability in the profession of teaching. Data obtained by using the interviews and surveys. For data analysis, Shapiro- Wilk Test, Distribution, frequency, correlations, and descriptive statistics are used. It has several of the independent variable extrinsic and intrinsic factors such as workplace support, workplace, perceptions, climate, school level, and work experience. The analysis revealed that both intrinsic and extrinsic factors affect teachers at their job. The choice of entering to teaching, view of teachers about themselves as the professionals, and support development have notable effects on the job satisfaction of teachers. On the survey method, the descriptive methods depend.

Anastasiou and Papakonstantinou (2014) converged the analyzed data with help of SPSS (Statistical Package for Social Sciences). Descriptive statistics, like frequencies and percentages for studying the stress levels and teacher's job satisfaction, was used by them. The goal of their research was to check the levels of stress and job satisfaction of secondary level's teachers in Greece NW. The research study revealed that teachers are satisfied with their jobs like they are satisfied to help their students, the capability to do work and the nature of their work but they are not satisfied with a condition that they are working with the women showcasing the elevated levels of stress and with the younger women. Environmental factors like provision of the ethical rewards, motivation by the principal of the school, decision making, and lastly the 
participation in the administration of the school help in producing the positive change and effect on the job performance of the teachers.

Moreover, Alshehry (2014), she used a qualitative approach to Saudi Arabia. She semistructured the interviews with observations depended on the qualitative data. The sample of this study have the academic teachers that are belonging to the University of Najran. Most teachers are chosen randomly from different colleges. The results revealed that the teachers have issues in solving the practical problems in applying the fresh syllabus, using enough supplementation for the process of teaching or understand the proof of methods of evaluation that was introduced by the students on achievements of the teachers. Based on these results, it is mandatory to accept perception of teachers under the consideration in the growth of methods of curriculum, exam system, evaluating the system, facilities, and resources. The participation of teachers will form ownership and allow them to have the energetic part in teaching the students with more devotion and commitment to evaluation. This will have revealed notable improvement in processes of the teaching of science in all the colleges.

Christopher (2014) also made research on the satisfaction of teachers. His used the quantitative and qualitative paradigms, interviews and questionnaires for collecting the data from a group of teachers and principals in public and private secondary schools in District Laang'ata in Nairobi. The nature of his research was descriptive. The results showed that the teacher's satisfaction level based on the environment that permits for personal and development growth and on salary as well as the level of encouragement and recognition.

Likewise, the study exposed that factors affecting the job satisfaction of teachers include interpersonal relations, flexible curriculum, involvement of the teachers in decision making in schools, fringe benefits, flexible timetable of schools, ordinary working hours, independence to fulfill own duties without any interference, job security, transfers by the school's managers, and the communication network between the staff and administration.

The job satisfaction is considered as the reason for scantiness. Job satisfaction of teachers need to increase and the guidance or the counseling of secondary school's teachers should be planned. The schools should give promotions on the base of merit. Training should become compulsory for teachers. All this will help in the professional expertise. Moreover, most schools must start the welfare programs for the needy teachers.

In Saudi Arabia, Al Doghan and Al Bar (2015) used the method of questionnaires that are collected and analyzed through the statistical package for the social sciences and expressed by the multiple linear testing calculation the linkage of motivation factors and employee performance and testing the hypothesis. So, it is established that there is the vast number of crucial factors like the income of the employees, organizational atmosphere and style of the leadership in private schools of Saudi Arabia. Age, year of experience and the education level are three demographic variables that enclosed in this study. Two main motivational factors are benefits and the salary. These two factors are at high ranking than the other factors. The other significant factor is a style of leadership. There is a notable positive relationship between salaries in the performance of the employees and the leadership style in private schools of Saudi Arabia. Moreover, there is an irrelevant and positive relationship between the environmental factors on the performance of the employees in private schools of Saudi Arabia. There is a negative and an irrelevant relation between a steady future and the employee's performance in the private schools of Saudi Arabia. 
Matoke et al. (2015) tried to find out the impacts of atmosphere factors, development factors, leadership factors and the compensation on teacher motivation. The data is collected with the help of questionnaires. Analysis of data has been done with the help of SPSS. Percentages and the frequencies are used for analysis of data. To record the effects of the independent variables on teacher's motivation, regression analysis has been used. Regression analysis also applied to the samples of teachers who are teaching in Masaba. This study revealed that all the factors have an impact on the motivation and substantial effects on the motivation of teachers are due to compensation factors.

Song and Mustafa (2015) surveyed in the associations among levels of teacher's job satisfaction, school's curriculum support and a number of the science teachers. The independent variables are a college degree, teaching experience, certification, subject area, gender, age, leadership, school size participation with others, professional development, and program supports. The dependent variable is job satisfaction. Qualitative data have 50 interviews of the principals from 50 multiple schools in Texas. The quantitative data was collected with the help of 385 surveys. These surveys were done from the science teachers that were doing their jobs in those schools. The analysis of data done by ANOVA and the correlation analysis was done by using SPSS, to investigate how science teachers at the multiple high schools affected their job satisfaction. The analysis of data revealed that most schools more resources to the science teachers than the smaller one. Teacher's job satisfaction is not connected with the number of science teachers and the number of schools. The survey also proved that the new teachers show their needs for the emotional support from parents, mentor, and administrators.

Saiti and Papadopoulos (2015) surveyed, with the help of empirical analysis, the view of teachers of primary schools related to their job satisfaction and investigated either the personal attributes of the primary school's educators like exact year, education level, family, status, gender, and age that provides service in primary education, have impact on their job satisfaction. So, 360 questionnaires were given to the primary school's teachers in the metropolitan area of Attiki. All that samples were collected randomly. The analysis of data is done by the descriptive analysis such as standard deviation and mean, and the correlation. The results showed that teachers of Greek schools are satisfied with their jobs or profession. Between the personal characteristics, statistical correlation did not exist and the teachers are completely satisfied with the three aspects of the job satisfaction that are nature of their job, administration, and colleagues and their least satisfaction with the potential rewards, salary, and benefits. Age-linked with levels of satisfaction along with the reference of the administration, colleagues, potential rewards, and the nature of the job. The full satisfaction depends on nine factors of job satisfaction. Moreover, gender, they noticed, impacted features of promotion and colleagues.

Rashid et al. (2016) surveyed different subjects of the teacher's motivation in the public sectors within higher educational institutions of Pakistan. The data was collected with the help of questionnaires and through interviews that were done face to face. The results of uncovered exams that although budgetary motivators and the pay bundles are compulsory elements for the presenters in the condition of the aggressive market, some other elements like workplace and occupation plan, preparing, the executives' framework, and the improvement are critical. The exams added different problems checked by the instructor in the open segment HEI identified with mentioned elements previously. 
In her survey, Naz (2017) surveyed the impacts of the self-adequacy, work conditions, work objectives, constructive outcomes, and the objectives helpful on the activity of the instructor. The extent of the examination was enclosed to Karachi's teachers. For examination, the selfcontrol poll from writing was selected. The prepared model tried with the help of SEM. Preceding evaluating ordinariness, guessed model, the legitimacy of develops, and the unwavering quality on the available informational index was examined.

Ohide and Mbogo (2017) examined the part of statistic factors that are influencing the fulfillment of job of the educators in private schools and in their following execution. In order to achieve the target, the developers finished the review study in private schools in South Sudan, Yei town. The simple method of irregular testing is utilized to select respondents from 10 private schools in town. Research studies are utilized for accumulating information. The information is broken down by utilizing SPSS (Statistical Package for the Social Sciences) and showed in the rates and frequencies. The components differentiated involved age section, sex, pay, length of the administration of the educators, and the instructive dimension. With the help of the searched results, it is proven that some of the statistic factors affect the employment of the instructors in the schools that are tuition based.

The survey also was done by Iwu et al. (2017). The independent factors are job properties and the job qualities, the conditions of auxiliary work: Leadership, supervision, status, job title, interpersonal relationship, reward, recognition, and growth opportunities. The following important conditions of work impact on required variables are job satisfaction and motivation: job security, obligations of work conditions, pat compensation and the duties. The examination used the quantitative method for a survey that is regulated to the 547 instructors in the 23 schools (nursery to the senior secondary schools) in Ibadan Southwest government area in Nigeria, in Oyo state. The SPSS programming was used for the information examination. The graphics investigation like standard deviation and mean, and the factor of the examination was used. The trial of Kolmogorov-Smirnov's and the Shapiro-Wilk of the ordinariness is likewise connected. The results recommended that the instructors pay or compensation, duties joined to the job and the development opening is three main attributes that added to the educator work.

Another survey is done by Kouli (2017) on the act of Cypriot school principal and its effects on the activities of the instructor. As mentioned by Kouali the motivation shows the results of the act of the principals of Cypriot school, instructional work and its effects on the activity of educators. Moreover, the activity of most instructors can be preceding when the principal of schools achieves and manage their instructional agreement. The quantitative methods are used together along with the subjective strategies like interviews, perceptions, a collection of antiques, and the casual discussions. The informational surveys are completed by several relapse examinations. The consequences of multiple relapse examination show that most of the amount of activity of educators are not anticipating when the principal achieved and managed their educational agreements.

Nigama et al. (2018) are examined the fulfillment activity between the teachers. The main theme of this survey is to look at fulfillment dimensions of female and male representatives that are working in private and public schools. This organized survey is controlled to gather valuable information. The survey was structured on only five points as the scale go from the unequivocally differs to an emphatically concur. 50 respondents from private school and 50 from administration school showed their interests in his investigation. The information is a breakdown with the graphics measurements using SPSS rendition 16. After checking the 
fulfillment level of activity between public and private teachers, it is discovered that there is no specific difference in their fulfillment dimensions despite the sexual orientation.

Most studies focus on job satisfaction of the teachers, motivation, and the performance using numerous factors like the personal characteristics, the environmental factors like a classroom and the school curriculum. Teacher's salaries and the rewards are included in motivational factors. Most studies use the method of SPSS for analyzing data. The demographic data is used in these studies are education level, years of experience, and the age. Most of the surveys prove that the financial incentive really affects the teacher's job satisfaction. This survey is interested in finding the effect of factors on the satisfaction of Saudi Arabia teachers. This study will also helpful for those who are interested in the development of the performance of the teachers of Saudi Arabia.

\section{Research Design}

\section{RESEARCH METHODOLOGY}

This study designed to determine the factors influence teachers' job satisfaction at secondary public schools in Buraidah city. This chapter describes the method used in the study to collect and analyze data.

\section{Type of study:}

This study is quantitative; in order to study the factors, influence teachers' job satisfaction at secondary public schools in Buraidah city.

\section{The model of study}

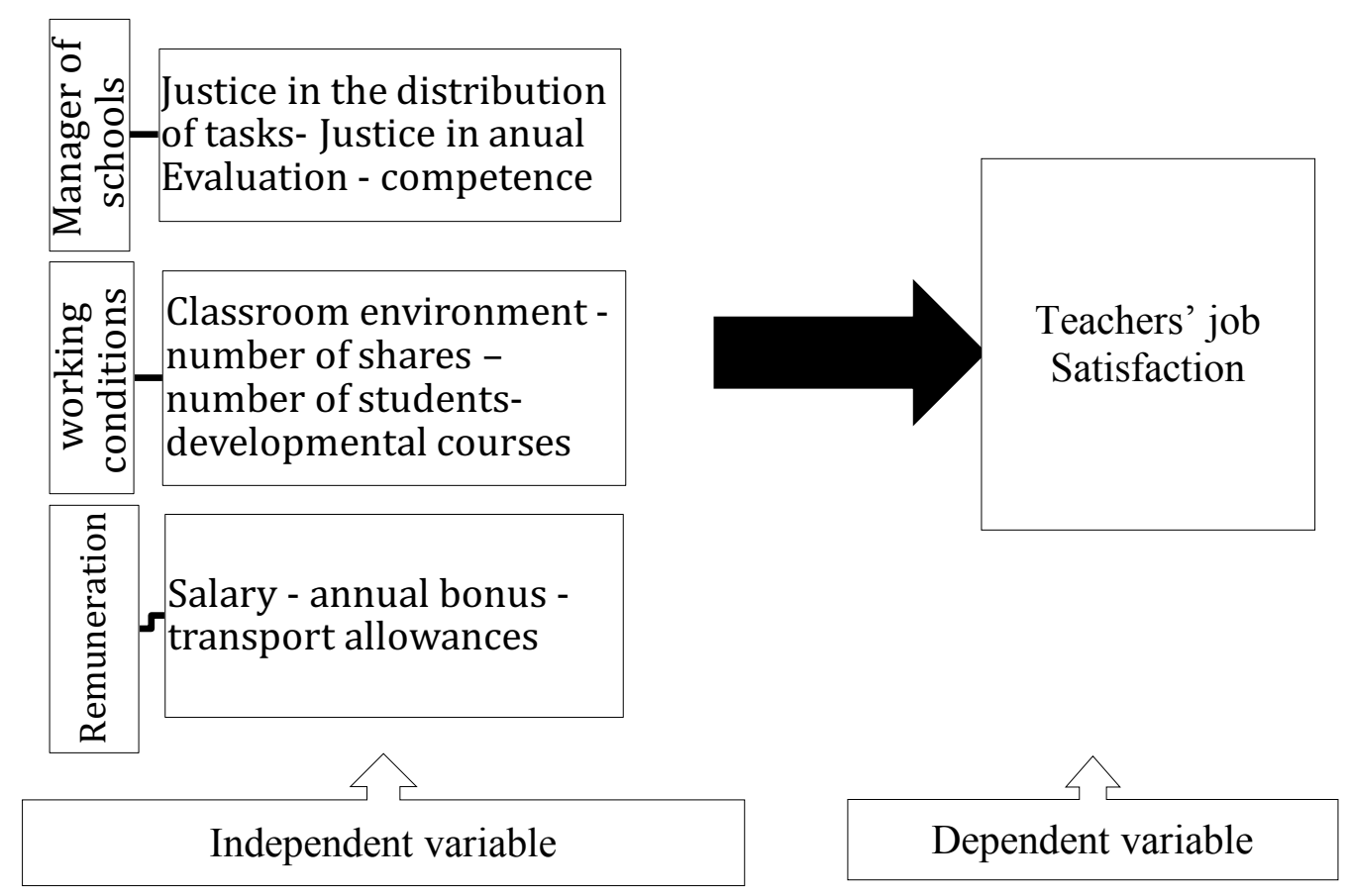

This Figure illustrates the factors that affect job satisfaction of teachers at secondary public schools in Buraidah city. In this case, manager of schools, working Conditions and remuneration is independent variables that effect on teachers' job satisfaction is dependent variable. In this study, the independent variables and the dependent variable measured using a questionnaire distributed to each study sample. 


\section{Hypothesis}

H10: There is no effect of school manager on teachers' job satisfaction, at secondary public schools in Buraidah city.

H1A: There are positive effect between school managers and teachers' job satisfaction, at secondary public schools in Buraidah city.

H2o: There are no effect between working conditions and teachers' job satisfaction, at secondary public schools in Buraidah city.

H2A: There are positive effect between working conditions and teachers' job satisfaction, at secondary public schools in Buraidah city.

H3o: There is no effect between Remuneration and teachers job satisfaction, at secondary public schools in Buraidah city.

H3A: There is positive effect between Remuneration and teachers' job satisfaction, at secondary public schools in Buraidah city.

\section{DATA COLLECTION METHODS}

Data has been collected through a survey distributed to all members of the sample by use electronic questionnaires. The questionnaire has three sections. First section consisted of closed questions of dependent and independent variables, second section consisted of openend question that requires respondents to express their personal views on the barriers that affect teachers 'job satisfaction, third section consisted of personal information for teachers at secondary public schools in Buraidah city. Using Likert scale (strongly disagree, disagree, neutral, agree and strongly agree). It distributed stratified randomly to 150 Saudi teachers at 30 secondary public schools in Buraidah city.

\section{Sampling Design \\ Population}

Population of the study include Saudi teachers in secondary public schools in Buraidah city in Qassim region, Saudi Arabia of general education in the morning. the sample consists of 150 Saudi teachers, from 30 secondary schools of general education in the morning in Buraidah city in Qassim region, Saudi Arabia. Distributed as follows: 75males teachers from 15 secondary schools and 75 female teachers from 15 secondary school, in Buraidah city of Al-Qassim in Saudi Arabia.

\section{Sample}

The stratified randomly the sample consists of 150 Saudi teachers, from 30 secondary schools of general education in the morning in Buraidah city in Qassim region, Saudi Arabia. Distributed as follows: 75males teachers from 15 secondary schools and 75 female teachers from 15 secondary school, in Buraidah city of Al-Qassim in Saudi Arabia. Schools and teachers were randomly selected.

\section{Statistical analysis technique}

Statistical techniques used:

- Descriptive Statistics.

- Correlations analyses.

- Factor analysis.

- Multiple regression.

- Reliability analyses.

\section{Data Analysis Software}

Data analysis software that will used to carry out factor analysis will be Statistical Package for Social Sciences (SPSS). 


\section{DATA ANALYSIS AND INTERPRETATIONS}

This section use SPSS program to analysis the predetermined alternative hypotheses $\mathrm{H} 1, \mathrm{H} 2$ and H3. The function of this statistical analysis was to identify the relationship between the independent variables (school manager, working conditions and remuneration) that affect job satisfaction, which is the dependent variable. Analysis and discussion of data gathered from the questionnaire is done in this section with descriptive statistics and the use of correlation to test the significant factors influencing teachers' job satisfaction in public secondary schools.

\section{Demographic Profile}

Table 1. Demographic information of the sample

\begin{tabular}{|c|c|c|c|c|}
\hline & Frequency & Percent & Valid Percent & Cumulative Percent \\
\hline $\begin{array}{cc}\text { Valid } & \text { Male } \\
& \text { female } \\
& \text { Total }\end{array}$ & $\begin{array}{c}75 \\
75 \\
150\end{array}$ & $\begin{array}{c}50.0 \\
50.0 \\
100.0\end{array}$ & $\begin{array}{c}50.0 \\
50.0 \\
100.0\end{array}$ & $\begin{array}{c}50.0 \\
100.0\end{array}$ \\
\hline $\begin{array}{l}\text { Age } \\
23-27 \\
28-32 \\
33-37 \\
38 \text { and more } \\
\text { Total }\end{array}$ & $\begin{array}{c}9 \\
36 \\
30 \\
75 \\
150\end{array}$ & $\begin{array}{c}6.0 \\
24.0 \\
20.0 \\
50.0 \\
100.0\end{array}$ & $\begin{array}{c}6.0 \\
24.0 \\
20.0 \\
50.0 \\
100.0\end{array}$ & $\begin{array}{c}6.0 \\
30.0 \\
50.0 \\
100.0\end{array}$ \\
\hline $\begin{array}{l}\text { Income } \\
7500-10999 \\
11000-14999 \\
15000 \text { and more } \\
\text { Total }\end{array}$ & $\begin{array}{c}54 \\
68 \\
28 \\
150\end{array}$ & $\begin{array}{c}36.0 \\
45.3 \\
18.7 \\
100.0\end{array}$ & $\begin{array}{c}36.0 \\
45.3 \\
18.7 \\
100.0\end{array}$ & $\begin{array}{c}36.0 \\
81.0 \\
100.0\end{array}$ \\
\hline $\begin{array}{l}\text { Experience } \\
0-5 \text { years } \\
6-11 \text { years } \\
12 \text { and more } \\
\text { Total }\end{array}$ & $\begin{array}{c}54 \\
68 \\
28 \\
150\end{array}$ & $\begin{array}{c}36.0 \\
45.3 \\
18.7 \\
100.0\end{array}$ & $\begin{array}{c}36.0 \\
45.3 \\
18.7 \\
100.0\end{array}$ & $\begin{array}{c}36.0 \\
81.0 \\
100.0\end{array}$ \\
\hline
\end{tabular}

\section{Descriptive Statistics}

Table 2: Descriptive Statistics

\begin{tabular}{|l|c|c|c|c|c|c|c|c|}
\hline & $\mathrm{N}$ & Range & Minimum & Maximum & Sum & \multicolumn{3}{|c|}{$\begin{array}{c}\text { Std. } \\
\text { Dean }\end{array}$} \\
\cline { 2 - 9 } & Statistic & Statistic & Statistic & Statistic & Statistic & Statistic & $\begin{array}{c}\text { Std. } \\
\text { Error }\end{array}$ & Statistic \\
\hline Satisfaction & 150 & 6.00 & 1.50 & 7.50 & 464.00 & 3.0933 & .13306 & 1.62962 \\
Manager & 150 & 12.00 & 3.25 & 15.25 & 1127.50 & 7.5167 & .23458 & 2.87296 \\
Working Conditions & 150 & 9.33 & 2.33 & 11.67 & 737.00 & 4.9133 & .20948 & 2.56560 \\
Remuneration & 150 & 10.00 & 6.25 & 16.25 & 1790.25 & 11.9350 & .18069 & 2.21296 \\
Valid N (leastwise) & 150 & & & & & & & \\
\hline
\end{tabular}

Table 2 shows descriptive statistics (mean and standard deviations) for the three dependent variables across the 150 teachers sampled. The mean scores across all variables ranged from 11.93 to 4.91 . It was revealed that the teachers' job satisfaction influencing by remuneration 
received the highest rating at secondary public schools with $M=11.93$ with $S D=2.213$, followed by school managers of the teachers' with $\mathrm{M}=7.52$ with $\mathrm{SD}=2.872$ and least of the variable is working conditions influence on secondary public teachers with $\mathrm{M}=4.91$ with $\mathrm{SD}=$ 2.566. This implies that, remuneration has great influence on the teachers' job satisfaction and working conditions has the least effect on the teachers' job satisfaction at secondary public schools of the study.

\section{Correlation analyses}

Table 3: Correlation for the factors influencing teachers' job satisfaction

\begin{tabular}{|ll|c|c|c|c|}
\hline & & & Working & \\
& & Satisfaction & Manager & conditions & Remuneration \\
\hline satisfaction & Pearson Correlation & 1 & $.609^{* *}$ & $.601^{* *}$ & $.922^{* *}$ \\
& Sig. (2-tailed) & & .000 & .000 & .000 \\
& $\mathrm{~N}$ & 150 & 150 & 150 & 150 \\
\hline
\end{tabular}

Table4: Correlation for the factors influencing teachers' job satisfaction

\begin{tabular}{|ll|c|c|c|c|}
\hline & Satisfaction & $\begin{array}{c}\text { School } \\
\text { manager }\end{array}$ & $\begin{array}{c}\text { Working } \\
\text { conditions }\end{array}$ & Remuneration \\
\hline Spearman's rhoSatisfaction & $\begin{array}{l}\text { Correlation } \\
\text { Coefficient } \\
\text { Sig. (2-tailed) }\end{array}$ & 1.000 & $.393^{* *}$ & $.382^{* *}$ & $.778^{* *}$ \\
$\mathrm{~N}$ &. & .000 & .000 & .000 \\
& 150 & 150 & 150 & 150 \\
\hline
\end{tabular}

By means of correlation, the relationship for the factors influencing teachers' job satisfaction at secondary public schools were tested for the three hypothesis in this study as revealed in table 3.

$\mathbf{Q}_{1}$ : How the manager of schools influences the teachers' job satisfaction, from the perspective of teachers at public secondary schools?

H10: There is no effect between school manager and teachers job satisfaction, at secondary public schools.

$\mathbf{H}_{1}$ A: There are positive effect between school managers and teachers' job satisfaction, at secondary public schools.

The table 3 shows the effect between school managers and teachers' job satisfaction, at secondary public schools in the study with $\mathrm{p}<.05$, the test is significant (There is a significant effect for school manager's influence on teachers' job Satisfaction). This implies that, there are positive effect between school managers and teachers' job satisfaction, at secondary public schools, $r(150)=.609 . p=.000$ and the null hypothesis is rejected.

Q2: How do working conditions influence teachers' job satisfaction, from the perspective of teachers at public secondary schools?

$\mathbf{H}_{2} \mathbf{0}$ : There are no effect between working conditions and teachers' job satisfaction, at secondary public schools.

$\mathbf{H}_{2} \mathbf{A}$ : There are positive effect between working conditions and teachers' job satisfaction, at secondary public schools.

The table 3 also shows the effect between working conditions and teachers' job satisfaction, at secondary public schools in the study with $\mathrm{p}<.05$, the test is significant (There is significant 
effect for working conditions influence on teachers' job Satisfaction). This implies that, there are positive effect between working conditions and teachers' job satisfaction, at secondary public schools, $\mathrm{r}(150)=.601 . \mathrm{p}=.000$ and the null hypothesis is rejected.

Q3: How does remuneration influence teachers' job satisfaction, from the perspective of teachers at public secondary schools?

$\mathbf{H}_{3} \mathbf{0}$ : There is no effect between Remuneration and teachers job satisfaction, at secondary public schools

$\mathbf{H}_{3} \mathbf{A}$ : There is positive effect between Remuneration and teachers' job satisfaction, at secondary public schools

Concerning remuneration effect with teachers' job satisfaction, at secondary public schools in the study with $\mathrm{p}<.05$, the test is significant (There is a significant relationship for remuneration influence on teachers' job Satisfaction). This implies that, there is positive effect between Remuneration and teachers' job satisfaction, at secondary public schools, $\mathrm{r}(150)=$ .922. $\mathrm{p}=.000$ and the null hypothesis is rejected.

\section{Factors analyses}

Table 5: KMO and Bartlett's Test

Kaiser-Meyer-Olkin Measure of Sampling Adequacy.

Bartlett's Test of Sphericity

Approx. Chi-Square

.613

Df

Sig.

6

.000

It is clear from the table 6 that the value of KMO (.613) which is greater than (0.50), this indicates increased reliability of the factors, also indicates the adequacy of the sample size, as the value of the significance level Barrlett equal $(0,000)$ is less than $(0,050)$ and this confirms the existence of a statistically significant relationship, so the analytical.

Table 6: Anti-image Matrices

\begin{tabular}{|c|c|c|c|c|c|}
\hline & & Satisfaction & Manager & $\begin{array}{c}\text { Working } \\
\text { conditions }\end{array}$ & Remuneration \\
\hline \multirow[t]{3}{*}{ Anti-image Covariance } & Manager & $-.024-$ & .752 & .077 & $-.051-$ \\
\hline & $\begin{array}{l}\text { Working } \\
\text { conditions }\end{array}$ & $-.010-$ & .077 & .980 & $-.014-$ \\
\hline & Remuneration & $-.133-$ & $-.051-$ & $-.014-$ & .147 \\
\hline \multirow[t]{4}{*}{ Anti-image Correlation } & & $.573^{a}$ & $-.072-$ & $-.027-$ & $-.897-$ \\
\hline & manager & $-.072-$ & $.926^{\mathrm{a}}$ & .090 & $-.153-$ \\
\hline & $\begin{array}{l}\text { Working } \\
\text { conditions }\end{array}$ & $-.027-$ & .090 & $.704^{\mathrm{a}}$ & $-.037-$ \\
\hline & remuneration & $-.897-$ & $-.153-$ & $-.037-$ & $.570^{\mathrm{a}}$ \\
\hline
\end{tabular}

a. Measures of Sampling Adequacy(MSA)

The MSA overall and for each individual variable are sufficiently large. The MSA value should be larger than 0.5. The Measures of Sampling Adequacy (MSA) for satisfaction value is equal to .573 while manager is .926. The working conditions MSA value is equal to .704 and remuneration .570 . 
Table7: Communalities

\begin{tabular}{|l|c|c|}
\hline & Initial & Extraction \\
\hline Satisfaction & 1.000 & .888 \\
Manager & 1.000 & .556 \\
Working condition's & 1.000 & .964 \\
Remuneration & 1.000 & .897 \\
\hline
\end{tabular}

Extraction Method: Principal Component Analysis.

Communalities shows how much of variance. It value should be more than 0.5 . Satisfaction is $88 \%$ of variance accounted for. Manager is $55 \%$ of variance accounted for. Working condition is $96 \%$ of variance accounted for. Remuneration is $89 \%$ of variance accounted for.

Table 8: Total Variance Explained

\begin{tabular}{|c|c|c|c|c|c|c|}
\hline \multirow[b]{2}{*}{ Component } & \multicolumn{3}{|c|}{ Initial Eigenvalues } & \multicolumn{3}{|c|}{ Extraction Sums of Squared Loadings } \\
\hline & Total & $\begin{array}{c}\% \text { of } \\
\text { Variance }\end{array}$ & $\begin{array}{c}\text { Cumulative } \\
\%\end{array}$ & Total & $\%$ of Variance & Cumulative \% \\
\hline 1 & 4.317 & 25.396 & 25.396 & 4.317 & 25.396 & 25.396 \\
\hline 2 & 2.119 & 12.462 & 37.858 & 2.119 & 12.462 & 37.858 \\
\hline 3 & 1.752 & 10.303 & 48.161 & 1.752 & 10.303 & 48.161 \\
\hline 4 & 1.425 & 8.383 & 56.544 & 1.425 & 8.383 & 56.544 \\
\hline 5 & 1.213 & 7.137 & 63.681 & 1.213 & 7.137 & 63.681 \\
\hline 6 & 1.095 & 6.442 & 70.123 & 1.095 & 6.442 & 70.123 \\
\hline 7 & .980 & 5.766 & 75.889 & & & \\
\hline 8 & .891 & 5.242 & 81.131 & & & \\
\hline 9 & .792 & 4.661 & 85.791 & & & \\
\hline 10 & .680 & 3.997 & 89.788 & & & \\
\hline 11 & .582 & 3.423 & 93.212 & & & \\
\hline 12 & .420 & 2.474 & 95.685 & & & \\
\hline 13 & .301 & 1.768 & 97.453 & & & \\
\hline 14 & .250 & 1.472 & 98.926 & & & \\
\hline 15 & .183 & 1.074 & 98.000 & & & \\
\hline 16 & .161 & .643 & 98.000 & & & \\
\hline 17 & .151 & .605 & 99.000 & & & \\
\hline
\end{tabular}

Extraction Method: Principal Component Analysis.

Table 8 shows that factor 1 explains a large amount of variance, as well as the other first few factors, while the next factors interpret small amounts of variance. 


\begin{tabular}{|c|c|c|c|c|c|c|}
\hline \multicolumn{7}{|c|}{ Table 9} \\
\hline & \multicolumn{6}{|c|}{ Component } \\
\hline & 1 & 2 & 3 & 4 & 5 & 6 \\
\hline My transport allowance is satisfactory & .955 & & & & & \\
\hline My salary is satisfactory & .955 & & & & & \\
\hline My school principal is fair in distributing tasks & .882 & & & & & \\
\hline My annual bonus is satisfactory & .860 & .173 & .153 & & $-.121-$ & \\
\hline $\begin{array}{l}\text { My school principal is fair in the annual } \\
\text { evaluation }\end{array}$ & .767 & .128 & & & .173 & -.163 \\
\hline My school principal has enough competence to & .124 & $-.893-$ & .403 & & & \\
\hline My School Manager are satisfactory & .124 & -893- & 403 & & & \\
\hline School principal has effect on my job & & & & & & \\
\hline satisfaction & $-.260-$ & .332 & .623 & $-.167-$ & & \\
\hline $\begin{array}{l}\text { Courses development effect on my job } \\
\text { satisfaction }\end{array}$ & $-.276-$ & .367 & .566 & .149 & .202 & $-.154-$ \\
\hline $\begin{array}{l}\text { The classroom environment has the most } \\
\text { effect on my job satisfaction }\end{array}$ & .111 & & $-.143-$ & .649 & .323 & \\
\hline $\begin{array}{l}\text { The ship number between }(18-15) \text { is } \\
\text { satisfactory }\end{array}$ & .137 & & .363 & .563 & $-.205-$ & \\
\hline $\begin{array}{l}\text { Courses offered by the Department of } \\
\text { education are satisfactory }\end{array}$ & $-.290-$ & & .223 & .483 & & -.336 \\
\hline $\begin{array}{l}\text { number of students between }(20-25) \text { are } \\
\text { satisfactory }\end{array}$ & .154 & .222 & -.192- & .417 & .359 & .138 \\
\hline $\begin{array}{l}\text { The classroom environment provides teaching } \\
\text { tools such as projector, and other are } \\
\text { satisfactory }\end{array}$ & $-.207-$ & .267 & .373 & .193 & -.637- & .218 \\
\hline $\begin{array}{l}\text { Fewer ship number has the most effect on my } \\
\text { job satisfaction } \\
\text { number of students in class room has most } \\
\text { effect on my job satisfaction }\end{array}$ & .170 & .241 & .545 & $-.403-$ & .563 & .651 \\
\hline $\begin{array}{l}\text { Remuneration has the most effect on my job } \\
\text { satisfaction }\end{array}$ & & & & .121 & .331 & .647 \\
\hline
\end{tabular}

Extraction Method: Principal Component Analysis.

a. 6 components extracted.

Table 9 presents the loadings of the three variables on the six factors extracted.

\section{Reliability analyses}

Table 10: Case Processing Summary

\begin{tabular}{|c|c|c|c|}
\hline & & $\mathrm{N}$ & $\%$ \\
\hline \multirow[t]{3}{*}{ Cases } & Valid & 150 & 100.0 \\
\hline & Excluded & 0 & .0 \\
\hline & Total & 150 & 100.0 \\
\hline
\end{tabular}

a. Listwise deletion based on all variables in the procedure.

Table 11: Reliability Statistics

\begin{tabular}{|l|l|}
\hline Cronbach's Alpha & N of Items \\
\hline .717 & 19 \\
\hline
\end{tabular}

It is clear from the table 11 that the value Cronbach's Alpha.717, coefficient is good. 


\section{Multiple Regression analysis}

Table 12: Model Summary

\begin{tabular}{|c|c|c|c|c|c|c|c|c|c|c|}
\hline \multirow[b]{2}{*}{ Model } & \multirow[b]{2}{*}{$\mathrm{R}$} & \multirow[b]{2}{*}{ R Square } & \multirow[b]{2}{*}{$\begin{array}{l}\text { Adjusted } \\
\text { R Square }\end{array}$} & \multirow{2}{*}{$\begin{array}{l}\text { Std. Error } \\
\text { of the } \\
\text { Estimate }\end{array}$} & \multicolumn{5}{|c|}{ Change Statistics } & \multirow[b]{2}{*}{$\begin{array}{l}\text { Durbin- } \\
\text { Watson }\end{array}$} \\
\hline & & & & & $\begin{array}{c}\text { R Square } \\
\text { Change }\end{array}$ & $\begin{array}{c}\mathrm{F} \\
\text { Change }\end{array}$ & df1 & df2 & $\begin{array}{c}\text { Sig. F } \\
\text { Change }\end{array}$ & \\
\hline 1 & $.923^{a}$ & .852 & .849 & .63242 & .852 & 281.110 & 3 & 146 & .000 & 1.903 \\
\hline
\end{tabular}

a. Predictors: (Constant), remuneration, working conditions, manager.

b. Dependent Variable: satisfaction.

Table 12 indicates that the multiple correlation coefficient $\mathrm{R}$ is equal .923, which points a good level of prediction of the dependent variable: job Satisfaction. Also, R square is equal .852 implying that the independent variables: Manager, Working conditions, and Remuneration, explain $85.2 \%$ of the variation in the dependent variable: job Satisfaction. The regression model well-fits the data due to that adjusted $\mathrm{R}$ square is less than $\mathrm{R}$ square with a very small difference, where it equals 0.632 as shown in table. The Durbin-Watson $=1.903$, which is between the two critical values of 1.5- 2.5 and is close to 2 . Thus, there is no strong evidence of autocorrelation problem.

Table 13: ANOVA

\begin{tabular}{|ll|c|c|c|c|c|}
\hline & & & & & \\
Model & Sum of Squares & Df & Mean Square & F & Sig. \\
\hline 1 & Regression & 337.299 & 3 & 112.433 & 281.110 & $.000^{\mathrm{b}}$ \\
& Residual & 58.394 & 146 & .400 & & \\
& Total & 395.693 & 149 & & & \\
\hline
\end{tabular}

a. Dependent Variable: satisfaction

b. Predictors: (Constant), remuneration, working conditions, manager

Table 13 indicates that a value is sig 0,000 less than a value .05 . we reject the H0: There is no relationship between school manager, working conditions and remuneration and teachers job satisfaction, at secondary public schools, and accept the alternative HA: There are relationship between school manager, working conditions and remuneration and teachers' job satisfaction, at secondary public schools.

Table 14: Coefficients

\begin{tabular}{|c|c|c|c|c|c|c|c|c|c|c|c|c|c|}
\hline \multirow{2}{*}{\multicolumn{2}{|c|}{ Model }} & \multicolumn{2}{|c|}{$\begin{array}{c}\text { Unstandardize } \\
\text { d Coefficients }\end{array}$} & \multirow{2}{*}{$\begin{array}{c}\text { Standardized } \\
\text { Coefficients } \\
\text { Beta }\end{array}$} & \multirow[b]{2}{*}{$\mathrm{T}$} & \multirow[b]{2}{*}{ Sig. } & \multicolumn{2}{|c|}{$\begin{array}{c}95.0 \% \text { Confidence } \\
\text { Interval for B }\end{array}$} & \multicolumn{3}{|c|}{ Correlations } & \multicolumn{2}{|c|}{$\begin{array}{c}\text { Collinearity } \\
\text { Statistics }\end{array}$} \\
\hline & & B & $\begin{array}{l}\text { Std. } \\
\text { Error }\end{array}$ & & & & $\begin{array}{l}\text { Lower } \\
\text { Bound }\end{array}$ & $\begin{array}{l}\text { Upper } \\
\text { Bound }\end{array}$ & $\begin{array}{l}\text { Zero- } \\
\text { order }\end{array}$ & $\begin{array}{c}\text { Parti } \\
\text { al }\end{array}$ & Part & $\begin{array}{l}\text { Toler } \\
\text { ance }\end{array}$ & VIF \\
\hline \multirow[t]{4}{*}{1} & (Constant) & $-.051-$ & .316 & &. & .872 & $-.677-$ & .574 & & & & & \\
\hline & Manager & .038 & .023 & .067 & $\begin{array}{c}1.64 \\
7\end{array}$ & .102 & $-.008-$ & .083 & .609 & .135 & .052 & .613 & $\begin{array}{c}1.63 \\
0\end{array}$ \\
\hline & $\begin{array}{l}\text { Working } \\
\text { conditions }\end{array}$ & .010 & .024 & .013 & .411 & .682 & $-.037-$ & .056 & .109 & .034 & .013 & .979 & $\begin{array}{c}1.02 \\
2\end{array}$ \\
\hline & Remuneration & .558 & .026 & .879 & $\begin{array}{c}21.5 \\
25\end{array}$ & .000 & .507 & .610 & .922 & .872 & .684 & .606 & $\begin{array}{c}1.65 \\
0\end{array}$ \\
\hline
\end{tabular}

\section{a. Dependent Variable: satisfaction}

As shown in table 14 the standardized coefficients Beta of the variable of the remuneration is the highest value among the other variables and is equal .879 , meaning that the remuneration 
has a higher impact than other variables. The variable of the remuneration is significant where $\mathrm{t}$ value for the remuneration is equal .558, which is also highest value among variables. Sig. = 0.000 is below 0.05 , thus, the remuneration is a significant predictor of job Satisfaction.

Table 15: Collinearity Diagnostics

\begin{tabular}{|c|c|c|c|c|c|c|c|}
\hline \multirow[b]{2}{*}{ Model } & \multirow[b]{2}{*}{ Dimension } & \multirow[b]{2}{*}{ Eigenvalue } & \multirow[b]{2}{*}{$\begin{array}{l}\text { Condition } \\
\text { Index }\end{array}$} & \multicolumn{4}{|c|}{ Variance Proportions } \\
\hline & & & & (Constant) & Manager & $\begin{array}{l}\text { Working } \\
\text { conditions }\end{array}$ & Remuneration \\
\hline \multirow[t]{4}{*}{1} & 1 & 3.768 & 1.000 & .00 & .01 & .00 & .01 \\
\hline & 2 & .156 & 4.910 & .03 & .03 & .05 & .41 \\
\hline & 3 & .060 & 7.892 & .00 & .85 & .04 & .56 \\
\hline & 4 & .015 & 15.760 & .96 & .11 & .91 & .03 \\
\hline
\end{tabular}

a. Dependent Variable: satisfaction

Table 16: Residuals Statisticsa

\begin{tabular}{|l|c|c|c|c|c|}
\hline & Minimum & Maximum & Mean & Std. Deviation & $\mathrm{N}$ \\
\hline Predicted Value & 1.4624 & 7.1677 & 3.0933 & 1.50458 & 150 \\
Residual & $-2.44177-$ & 2.92928 & .00000 & .62603 & 150 \\
Std. Predicted Value & $-1.084-$ & 2.708 & .000 & 1.000 & 150 \\
Std. Residual & $-3.861-$ & 4.632 & .000 & .990 & 150 \\
\hline
\end{tabular}

a. Dependent Variable: satisfaction

\section{SUMMARY}

The motivation behind this examination was to research the components impacting educators' activity fulfillment in broad daylight auxiliary schools in Buraidah. The truth of impact work fulfillment in the educating, prompted the researcher to determine the factors that teachers job satisfaction. This study is quantitative; in order to study the factors, influence teachers' job satisfaction at secondary public schools in Buraidah city.

Data was collected using of questionnaire, which were distributed to 150 teachers in Buraidah, Saudi Arabia. Data was analyzed quantitatively by use of SPSS program, analysis and discussion of data gathered from the questionnaire is done with descriptive statistics and the use of correlation to test the significant factors influencing teachers' job satisfaction in public secondary schools in Buraidah city. Where the results proved that, remuneration, school manager and working conditions has influence on the teachers' job satisfaction. Remuneration has the great effect on the teachers' job satisfaction at secondary public schools of the study.

\section{CONCLUSION}

The development and adequacy of teacher performance is a key goal of educational systems in most countries of the world. This has prompted these systems to seek to identify the needs of the teacher and the factors that affect his level of performance. Various studies were conducted with a view to changing and modifying the traditional concept of the teacher's work, as the teacher is no longer a vector of information only, but has become a mentor, and organizer of the entire educational environment.

There a few factors that we can add up into levels of teacher job satisfaction. In this study, the impact of a number of factors on the satisfaction of the Saudi teacher in public schools in the city of Buraydah was discussed. It became clear from previous studies that there are many 
factors that affect the satisfaction of the teacher. This study proved that, remuneration, school manager and working conditions has influence on the teachers' job satisfaction. Remuneration has the great effect on the teachers' job satisfaction at secondary public schools of the study.

\section{THE RECOMMENDATIONS}

The study recommends the following:

- Ministry of education should provide concrete benefits such as health insurance for teachers and teacher's annual financial equivalents.

- Pay attention to the relationship between the principal and teachers.

- Managers must learn how to deal with teachers.

- There are a number of working conditions must be improved, such as the number of classes and students and developmental courses.

\section{References}

Ahmed, M., Hussain, I., Ahmad, S. and Din, Q., 2012. TheFactors AffectingThe Professional PerformanceOf Teachers At Higher Education Level In Pakhtunkhwa. Academic Research International, Vol. 2, No. 2, PP. 336-341.

Al Doghan, M., Al ban, S., 2015. Study on Influence of Motivation Factors on Employees Performance in Private Schools in Saudi Arabia. Journal of Human Resource and Sustainability Studies, Vol. 2015, 3, PP. 179-187

AlOmari, K., m., 2006. Factors influencing the performance of teachers in the first three grades of basic education from their point of view.magazine, Union of Arab Universities for Education and psychology. Union of Arab Universities for Education and psychology magazine, Vol. 4, 2, PP.121-150

Al-Rubaish, A. M., Rahim, S. I. A., Abumadini, M. S., \& Wosornu, L., 2009. Job satisfaction among the academic staaf of a saudi university: an evaluative study. Journal of Family \& Community Medicine, Vol. 16(3), PP. 97-103.

AlShehry, A., T., 2014. Investigating Factors Affecting Science Teachers' Performance and Satisfaction toward their Teaching Process at Najran University for Girls' Science Colleges in Saudi Arabia. International. Journal of Higher Education, Vol. 3, No. 2, PP. 73-83

Anastasiou, S., \& Papakonstantinou, G., 2014. Factors affecting job satisfaction, stress and work performance of secondary education teachers in Epirus, NW Greece. Int. J. Management in Education, Vol. 8, No. 1, PP.37-53

Bavec, C., 2010. Social Responsibility and Professional Ethics in Management: Does It Matter? 11th International Conference: Social Responsibility, Professional Ethics, and Management. pp. 75-88. Ankara, Turkey, 24-27 November 2010. Primorska: Slovenia.

Bengt, G., Lars, R., Gunnar, T., \& Peter, W., 1984. Focus on: The Uppsala code of ethics for scientists. Journal of Peace Research, 21(4)

Bird, S.J., 2014. Social Responsibility and Research Ethics: Not Either/or but Both. [Online]Available at: <https://www.aaas.org/news/social-responsibility-and-research-ethics-not-eitheror-both> [Accessed 9 Nov. 2018].

Bretag, T., and Mahmud, S., 2009. Self-Plagiarism or Appropriate Textual Re-Use. Journal of Academic Ethics, [ejournal] Vol. 7, No. 3, PP. 193-205

Bryman, A., and Bell, E., 2011. Business Research Methods. 3ed ed. Oxford: Oxford University Press.ch5.

Chistopher, N., 2014. FactorsInfluencing SecondarySchool Teachers'Job Satisfaction Levels In Langata District, Nairobi Department Of Education University Of Eldoret. International Journal of Community and Cooperative Studies, Vol.1, No.2, PP.12-26.

Delandshree, G., 2007. Literacy research, ethics and social responsibility. English Teaching: Practice and Critique, 6(3) pp 133-147.

Dantzker, M., and Hunter, R., 2011. Research and Ethics. ed. 2012. Research Methods for Criminology and Criminal Justice. London: Jones \& Bartlett Publishers. Ch. 2. pp. 19-30

Gurzawska, A. M., and Brey, P., 2015. Principles and Approaches in Ethics Assessment. [Online] available at: http://satoriproject.eu/media/1.c-Social-responsibility.pdf [Accessed 9 Nov. 2018].

Gustafsson, B., Ryden, L., Tibell, G. and Wallensteen, P. (1984). Focus on The Uppsala code of ethics for scientists. Journal of Peace Research, 21(4), pp.311-316. 
Iwu, C. G., Ezeuduji, I., Iwu, I., Ikebuaku, K., \& Tengeh, R., 2017. Achieving Quality Education by Understanding Teacher Job Satisfaction Determinants. Social Sciences Journal, Vol.10,33, PP. 2-13

Kasi,P .(2009). Research: What, Why and How?. AuthorHouse. Bloomington Indiana.

Kouali, G., 2017. The instructional practice of school principals and its effect on teachers job satisfaction. International Journal of Educational Management, Vol. 31, Issue: 7, PP.958-972.

Korn, L., \& Davidovitch, N., 2016. The Profile of Academic Offenders: Features of Students Who Admit to Academic Dishonesty. Medical science monitor: international medical journal of experimental and clinical research, Vol. 22, 3043-55, PP. 433

Koustelios, A., Theodorakis, N., and Goulimaris, D., 2004. Role ambiguity, role conflict and job satisfaction among physical education teachers in Greece. International Journal of Educational Management, Vol. 18 Issue: 2, PP.87-92, [Online]

Matoke, Y., K., Okibo, W., B., Nyamongo, D., N., 2015. Determinants of teacher motivation in public secondary schools in Masaba South-Sub Kenya. International Journal of Economics, Commerce and Management, Vol. 3, Issue 6, PP. 139-160

Ministry of educacation, 2016. Statistical information. [Online] Available at: https://www.moe.gov.sa/ar/Pages/StatisticalInformation.aspx

[Accessed 5 Nov 2017].

Nigama, k., Selvabaskar, S., Surulivel, S., Alamelu, R., and Juice, D., 2018. JOB SATISFACTION AMONG SCHOOL TEACHERS. International Journal of Pure and Applied Mathematics. Vol. 119, PP. 2645-2655

Ohide, A.,and Mbogo, R., 2017. Demographic Factors Affecting Teachers' Job Satisfaction and Performance in Private Primary Schools in Yei Town, South Sudan. IRA-International Journal of Education \& Multidisciplinary Studies, Vol.08, Issue 01, pp. 142-148

Obineli, A. S., 2013. Teachers' Perception of the Factors Affecting Job Satisfaction in Ekwusigo Local Government of Anambra State, Nigeria. An International Multidisciplinary Journal, Ethiopia, Vol. 7 (4), PP. 225-237

O’Reilly, P. E., 2014. Teachers at Work: Factors Influencing Satisfaction, Retention and the Professional Well-Being of Elementary and Secondary Educators. Graduate Center, City University of New York

Orb, A., Eisenhauer, L., and Wynaden, D., 2001. Ethics in Qualitative Research. Journal of Nursing Scholarship, [ejournal] Vol. 33, No. 1, pp. 93-96.

Rasheed, M., Humayon, A., Awan, U., and Ahmed, A., 2016. Factors affecting teachers' motivation: An HRM challenge for public sector higher educational institutions of Pakistan (HEIs). International Journal of Educational Management, Vol. 30 Issue: 1, pp.101-114.

Reilly, E., Dhingra, K., and Boduszek, D., 2014. Teachers' self-efficacy beliefs, self-esteem, and job stress as determinants of job satisfaction. International Journal of Educational Management, Vol. 28 Issue: 4, PP.365-378

A., and Papadopoulos, Y., 2015. School teachers' job satisfaction and personal characteristics A quantitative research study in Greece. International Journal of Educational Management, Vol. 29 Issue: 1, PP.73-97.

Schuurbiers, D., 2010. Social responsibility in research practice: Engaging applied scientists with the socio-ethical context of their work (Doctoral dissertation, TU Delft, Delft University of Technology).

Sekaran, U., 2003. Research methods for business. 4th ed. United States of America: John Wiley \& Sons, Inc.ch1.

Singh, J.K. and Jain, M. (2013). A Study of employee's job satisfaction and its impact on their performance. Journal of Indian research, 1(4), pp.105-111.

Song, S., and Mustafa, M., 2015. Factors Impacting on Teachers' Job Satisfaction related to Science Teaching: A Mixed Methods Study. Science Education International. Vol. 26, Issue 3, PP. 358-375

Stephanie, J., B. (2014). Professional Ethics Report. American Association for the Advancement of Science, 27(2).

Treputtharata, S., and Tayiam, S., 2013. School Climate affecting Job Satisfaction of Teachers. Elsevier Ltd. under responsibility of Academic World Education and Research Center,Vol. 116, PP. 996 - 1000

Wright, T. A., and Wright, V. P., 2002. Organizational Researcher Values, Ethical Responsibility, and the Committed-to-Participant Research Perspective. Journal of Management Inquiry. [e-journal] Vol. 11, No. 2, pp 173185. 
Zandvoort, H., Borsen, T., Deneke, M., \& Bird, S. J., 2013. Editors' overview perspectives on teaching social responsibility to students in science and engineering. Science and engineering ethics, 19(4), pp.1413-1438.

\section{APPENDIX A}

\section{Questionnaire}

\section{FACTORS INFLUENCING TEACHERS' JOB SATISFACTION A CASE STUDY OF PUBLIC SECONDRY SCHOOLS IN BURAIDH CITY SAUDI ARABIA}

\begin{tabular}{|c|c|c|c|c|c|c|}
\hline \multicolumn{7}{|c|}{ Please put $\sqrt{ }$ on the appropriate answer: } \\
\hline & \multicolumn{6}{|l|}{ Questions on teachers' job satisfaction } \\
\hline 1 & I am satisfied with my current job. & $\begin{array}{l}\text { Strongly } \\
\text { agree }\end{array}$ & agree & neutral & disagree & $\begin{array}{l}\text { Strongly } \\
\text { disagree }\end{array}$ \\
\hline \multirow[t]{2}{*}{2} & Anyway I am satisfied with my job & & & & & \\
\hline & \multicolumn{6}{|c|}{ Rate of impact of the school manager on your job satisfaction } \\
\hline 3 & My school principal is fair in distributing tasks. & $\begin{array}{l}\text { Strongly } \\
\text { agree }\end{array}$ & agree & neutral & disagree & $\begin{array}{l}\text { Strongly } \\
\text { disagree }\end{array}$ \\
\hline 4 & $\begin{array}{l}\text { My school principal is fair in the annual } \\
\text { evaluation. }\end{array}$ & & & & & \\
\hline 5 & $\begin{array}{l}\text { My school principal has enough competence to } \\
\text { work as a school manager. }\end{array}$ & & & & & \\
\hline 6 & My School Manager are satisfactory & & & & & \\
\hline \multirow[t]{2}{*}{7} & School principal has effect on my job satisfaction & & & & & \\
\hline & \multicolumn{6}{|c|}{ Rate of impact of the working conditions on your job satisfaction } \\
\hline 8 & $\begin{array}{l}\text { The classroom environment provides teaching } \\
\text { tools such as projector, and other are } \\
\text { satisfactory }\end{array}$ & & & & & \\
\hline 9 & $\begin{array}{l}\text { number of students between }(20-25) \text { are } \\
\text { satisfactory }\end{array}$ & & & & & \\
\hline 10 & $\begin{array}{l}\text { The ship number between (18-15) is } \\
\text { satisfactory. }\end{array}$ & & & & & \\
\hline 11 & $\begin{array}{l}\text { Courses offered by the Department of education } \\
\text { are satisfactory }\end{array}$ & & & & & \\
\hline 12 & $\begin{array}{l}\text { The classroom environment has the most effect } \\
\text { on my job satisfaction }\end{array}$ & & & & & \\
\hline 13 & $\begin{array}{l}\text { number of students in class room has most } \\
\text { effect on my job satisfaction }\end{array}$ & & & & & \\
\hline 14 & $\begin{array}{l}\text { Fewer ship number has the most effect on my } \\
\text { job satisfaction }\end{array}$ & & & & & \\
\hline \multirow[t]{2}{*}{15} & $\begin{array}{l}\text { Courses development has effect on my job } \\
\text { satisfaction }\end{array}$ & & & & & \\
\hline & \multicolumn{6}{|c|}{ Rate of impact of the remuneration on your job satisfaction } \\
\hline 16 & My salary is satisfactory & & & & & \\
\hline 17 & My annual bonus is satisfactory & & & & & \\
\hline 18 & My transport allowance is satisfactory & & & & & \\
\hline 19 & $\begin{array}{l}\text { Remuneration has the most effect on my job } \\
\text { satisfaction }\end{array}$ & & & & & \\
\hline \multicolumn{7}{|c|}{20 Do you face barriers effect on your job satisfaction } \\
\hline Yes ( & & No $(\quad)$ & & & & \\
\hline
\end{tabular}


Al Ajlan, H. (2019). Factors Influencing Teachers' Job Satisfaction: A Case Study Of Public Secondary Schools In Buraidh City Saudi Arabia. Advances in Social Sciences Research Journal, 6(3) 302-322.

If your answer is Yes. Write the barriers that effect on your job satisfaction

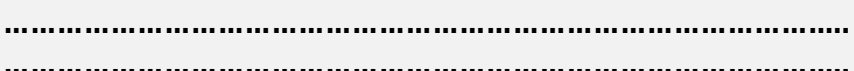

n.,

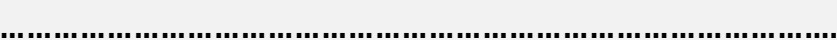

\section{Personal information}

\section{Name :}

Gender:

Male ( )

Female ( )

Age

$28-32()$

$33-37()$

38 and more ( )

23-27( )

Income level

7500 - 10999 ( )

$11000-14999$ ( ) 15000 and more ( )

Years of experience

0-5 years ( )

6-11 years ( )

12 and more ( ) 